\title{
PENGARUH KONSENTRASI MAIZENA DAN LAMA PEMASAKAN DENGAN SUHU TETAP TERHADAP KARAKTERISTIK LEMPOK APEL MANALAGI
}

\section{The Effect of Maizene Concentration and Cooking Time with Fixed Temperature on Manalagi Apple Lempok Characterization}

\author{
Annisa Ayu Pratiwi`, Wahono Hadi Susanto, Jaya Mahar Maligan \\ Jurusan Teknologi Hasil Pertanian, FTP Universitas Brawijaya Malang \\ JI. Veteran, Malang 65145 \\ *Penulis korespondensi, Email: pratiwi.annisa68@yahoo.com
}

\begin{abstract}
ABSTRAK
Total produksi apel di Kota Batu mencapai 22.000 ton/tahun. Namun, sekitar 4.000 ton apel belum dimanfaatkan secara optimal. Apel dapat diolah menjadi lempok yang merupakan pangan tradisional berbentuk semi basah. Pada proses pembuatan lempok, lama pemasakan dan konsentrasi penambahan maizena berpengaruh terhadap konsistensi gel. Penelitian ini bertujuan untuk mengetahui pengaruh dan interaksi penambahan konsentrasi maizena dan lama pemasakan dengan suhu tetap terhadap karakteristik lempok apel. Penelitian ini menggunakan Rancangan Acak Kelompok terdiri dari tingkat lama pemasakan yaitu 1, 1.5 dan 2 jam serta konsentrasi maizena 5, 7.5 dan 10\%. Data dianalisis dengan ANOVA dan dilanjutkan dengan uji lanjut BNT dan DMRT. Lama pemasakan dengan suhu tetap dan konsentrasi maizena berpengaruh terhadap karakteristik lempok apel manalagi. Hasil penelitian menunjukkan, lempok apel terbaik berdasarkan parameter kimia dan fisik adalah lempok apel dengan perlakuan lama pemasakan 2 jam dan konsentrasi maizena $10 \%$. Produk terbaik berdasarkan organoleptik adalah lempok apel dengan perlakuan lama pemasakan 1,5 jam dan konsentrasi maizena 7,5\%.
\end{abstract}

Kata Kunci : Apel, Lama Pemasakan, Lempok, Maizena

\section{ABSTRACT}

Apples production reached 22,000 tons/year. However, there are still about 4,000 tons of apples that have not been utilized optimally. Apple can be processed into lempok which was a traditional intermediate moisture food. In the process of making lempok, cooking time and maizene concentration have an effect on gel consistency. The aim of this study was to determine the influence and interaction of adding maizene concentration and cooking time with a fixed temperature to the characteristics of apple lempok. This study used a Randomized Block Design consisting of a cooking time rate of 1, 1.5 and 2 hours and maizene concentration of 5, 7.5 and 10\%. Data were analyzed by ANOVA and followed by BNT and DMRT. The cooking time with the fixed temperature and maizene concentration have an effect on the characteristic of manalagi apple. The results showed that the best apple lempok based on chemical and physical parameters was apple lempok with 2 hours cooking time and maizene concentration $10 \%$. The best product based on organoleptik was apple lempok with cooking time 1.5 hours and maizene concentration $7.5 \%$.

Keywords: Apples, Cooking Time, Lempok, Maizena

\section{PENDAHULUAN}

Produksi apel di Indonesia belum termanfaatkan secara optimal. Menurut BPS Kota Batu (2010), total produksi apel di daerah Kota Batu mencapai 22.000 ton/tahun, namun masih ada sekitar 4.000 ton apel yang belum termanfaatkan secara optimal. Apel di Indonesia 
sudah banyak dimanfaatkan sebagai bahan baku berbagai macam makanan olahan selain fungsi utamanya sebagai buah segar,diantaranya yaitu dodol apel, kripik apel, jenang apel, selai apel dan manisan apel. Untuk menambah diversifikasi produk olahan apel maka apel ini dapat diolah menjadi lempok apel. Lempok apel merupakan produk olahan apel yang belum dikembangkan. Lempok adalah makanan ringan yang berasal dari buah-buahan yang diolah dengan menambahkan gula sebagai pemanisnya.

Faktor utama yang menentukan pembuatan lempok adalah tingkat kematangan buah, lama pemasakan dan suhu. Lama pemasakan menjadi faktor penting karena proses pemasakan akan memodifikasi sifat fisik bahan untuk menghasilkan tekstur produk yang diinginkan. Lama pemasakan bertujuan untuk menguapkan air dan meningkatkan viskositas sehingga tekstur dari produk menjadi padat dan kalis. Untuk membentuk tekstur yang diinginkan maka perlu dilakukan penambahan pengental, dimana pengental akan mempercepat proses pemasakan karena pengental akan mengikat air sehingga viskositas produk juga akan meningkat lebih cepat. Pengental yang sering dipakai adalah maizena.

Pada saat pemasakan dengan penambahan pengental terjadi gelatinisasi pati dari pengental. Gelatinisasi adalah perubahan yang terjadi pada granula pada waktu mengalami pembengkakan yang luar biasa dan tidak dapat kembali ke bentuk semula (Winarno, 2002). Mekanisme proses gelatinisasi secara umum, yaitu air dan pati akan membentuk suatu sistem dispersi, karena pati mengandung amilosa dan amilopektin yang mengandung gugus hidroksil yang sangat besar. Gugus hidroksil akan bereaksi dengan hidrogen dari air. Pada keadaan dingin viskositas sistem dispersi pati air hanya berbeda sedikit dengan viskositas air, karena ikatan patinya masih cukup kuat sehingga air belum mampu masuk ke dalam granula pati. Setelah dipanaskan ikatan hidrogen antara amilosa dan amilopektin mulai lemah sehingga air semakin mudah terpenetrasi ke dalam susunan amilosa dan amilopektin. Waktu gelatinisasi yang terlalu lama serta adanya penguapan air yang tidak sempurna dimana uap air terjebak tidak dapat keluar menyebabkan pati mengalami retrogradasi

Berdasarkan hal tersebut, diperlukan formulasi pembuatan lempok berdasarkan tingkat kematangan dan konsentrasi penambahan maizena. Penelitian ini bertujuan untuk mengetahui pengaruh dan interaksi tingkat kematangan apel dan konsentrasi maizena terhadap karakteristik fisik, kimia, dan organoleptik lempok apel.

\section{BAHAN DAN METODE}

\section{Bahan}

Bahan yang digunakan dalam proses pembuatan lempok apel adalah apel Manalagi yang didapatkan dari perkebunan apel di Batu, Jawa Timur ; tepung maizena (merk RRT Xingmao) yang diperoleh dari toserba Prima Rasa serta bahan lain yang meliputi gula, margarin (merk Simas) dan metabisulfit. Sedangkan bahan yang digunakan untuk analisis adalah Glukosa anhidrat $\mathrm{H}_{2} \mathrm{SO}_{4}$ pekat $97 \%$, reagen Anthrone, $\mathrm{Pb}$ Asetat, $\mathrm{Na}$ Oksalat, alkohol $95 \%$, larutan $\mathrm{K}_{2} \mathrm{SO}_{4} 10 \%$, larutan $\mathrm{H}_{2} \mathrm{SO}_{4} 0,255 \mathrm{~N}, \mathrm{NaOH} 45 \%$, larutan amilum $1 \%$, larutan yodium $0.01 \mathrm{~N}$, asam askorbat, dan aquades

\section{Alat}

Alat yang digunakan dalam proses pembuatan lempok apel adalah baskom, pisau, loyang, kompor gas (merk Rinnai), wajan teflon, pengaduk kayu, timbangan (merk Scaleman S-95) dan blender (merk Miyako tipe BL-151 PF/AP). Alat yang digunakan untuk analisis adalah neraca analitik (merk Denver M 310 USA), kertas saring kasar, vortex-mixer (Model VM 2000), kompor listrik (merk Maspion), pendingin balik, spektrofotometer dan kuvet (UNICO RRC UV 2100), oven listrik (WTB Binder), desikator (merk Scoot Duran), Bola Hisap, buret, statip dan glassware (Pyrex).

\section{Desain Penelitian}

Desain penelitian menggunakan metode Rancangan Acak Kelompok (RAK) faktorial. Faktor I adalah lama pemasakan dengan suhu tetap terdiri dari 3 level ( 1 jam; 1,5 jam dan 2 jam). Faktor II adalah konsentrasi maizena yang terdiri atas 3 level (5\%; 7,5\% dan 10\%). Data 
yang diperoleh dianalisis dengan menggunakan metode Analysis of Variance (ANOVA) dan dilanjutkan dengan uji BNT dan DMRT dengan selang kepercayaan $5 \%$ dan $1 \%$. Data hasil uji organoleptik dianalisis menggunakan uji Hedonic Scale Scoring. Penentuan perlakuan terbaik menggunakan metode Zeleny

\section{Tahapan Penelitian \\ Proses Pembuatan Lempok Apel}

Apel manalagi dikupas kulitnya dan dibagi menjadi 4 bagian dan isinya dibuang. Ditimbang seberat $1 \mathrm{~kg}$. Lalu diblanching dengan ditambahkan air 1:1 dan metabisulfit 1000 ppm. Kemudian dihaluskan dengan menggunakan blender dengan kecepatan putar 7000 rpm selama 20 detik. Jadilah slurry apel, lalu dimasukkan maizena dengan konsentrasi yang berbeda $(5 \%, 7.5 \%$ dan $10 \%)$, gula $7.5 \%$ dan margarin $2.5 \%$. Selanjutnya dimasak dan diaduk dengan suhu tetap $80 \pm 2^{\circ} \mathrm{C}$ selama waktu yang berbeda ( 1 jam, 1.5 jam dan 2 jam). Setelah dingin kemudian lempok dikemas dan disterilisasi menggunakan steam selama 15 menit. Jadilah lempok apel yang siap dilakukan analisis.

\section{Prosedur Analisis}

\section{Analisis Kadar Air Metode Oven (Sudarmadji et al., 1997)}

Cawan alumunium foil dikeringkan dalam oven pada suhu $105^{\circ} \mathrm{C}$ selama 24 jam, lalu didinginkan dalam desikator selama 30 menit. Cawan ditimbang menggunakan timbangan analitik. Sampel sebanyak $1 \mathrm{~g}$ dimasukkan ke dalam cawan. Kemudian cawan serta sampel ditimbang dengan neraca analitik. Cawan berisi sampel dikeringkan dalam oven pada suhu $105^{\circ} \mathrm{C}$ selama 5 jam. Selanjutnya cawan berisi sampel didinginkan dalam desikator, kemudian ditimbang. Pengeringan dan penimbangan diulangi hingga diperoleh bobot konstan (selisih bobot $\leq 0.2 \mathrm{mg}$ ).

Kadar air $(\% \mathrm{~b} / \mathrm{b})=\frac{\text { berat sampel awal-berat sampel setelah dikeringkan }}{\text { berat awal }} \times 100 \%$

\section{Analisis Kadar Vitamin C Metode Uji lodium(Sudarmadji et al., 1997)}

Sampel dihancurkan sampai diperoleh bubur. Bubur ditimbang 10-30 g dan dimasukkan ke dalam labu ukur $100 \mathrm{ml}$ serta ditambah aquades sampai tanda batas. Filtrat dihomogenkan dan disaring. $25 \mathrm{ml}$ filtrat dimasukkan ke dalam erlenmeyer $100 \mathrm{ml}$ kemudian ditambahkan $1 \mathrm{ml}$ amilum 1\%. Filtrat dititrasi dengan larutan iodium standar $0.01 \mathrm{~N}$ sampai terjadi perubahan warna.

Kadar Vitamin $\mathrm{C}(\%)=\frac{\mathrm{ml} \text { iodium } \times 0,01 \mathrm{~N} \times 4 \times 88 \times 100}{\text { berat sampel }(\mathrm{mg})}$

\section{Analisis Kadar Total Gula Metode Anthrone (AOAC, 1990)}

Sampel ditimbang 3 gram, ditambahkan alkohol 80\% (1:2) kemudian dihancurkan dalam waring blender. Pindahkan ke dalam gelas beaker, saring sampel dan cuci alkohol $80 \%$. Ukur pH dan jika asam tambahkan 2 gram $\mathrm{CaCO}_{3}$. Panaskan dalam penangas air $100^{\circ} \mathrm{C}$ selama 30 menit. Sampel disaring lagi. Filtrat dipanaskan suhu $85^{\circ} \mathrm{C}$. Tambahkan $3 \mathrm{ml} \mathrm{Pb}$ asetat dan kemudian $\mathrm{Pb}$ asetat dihilangkan dengan penambahan 0.1 gram Na-oksalat, kemudian disaring lagi. Dimasukkan $1 \mathrm{ml}$ filtrat ke dalam tabung reaksi. Tambahkan $5 \mathrm{ml}$ pereaksi Anthrone kemudian vorteks hingga homogen. Panaskan tabung reaksi menggunakan waterbath $100^{\circ} \mathrm{C}$ selama 12 menit. Dinginkan menggunakan air mengalir. Ukur absorbansi pada panjang gelombang $630 \mathrm{~nm}$.

\section{Analisis Kadar Serat Kasar (AOAC, 1995)}

Sampel ditimbang $5 \mathrm{~g}$ dan dilarutkan dalam $100 \mathrm{ml} \mathrm{H}_{2} \mathrm{SO}_{4}\left(1.25 \mathrm{~g} \mathrm{H}_{2} \mathrm{SO}_{4}\right.$ pekat/100ml) kemudian dididihkan dengan pendingin balik selama 30 menit. Suspensi disaring melalui kertas saring halus dan residu yang tertinggal dalam kertas saring dicuci dengan akuades. Cucilah residu dalam kertas saring sampai air cucian tidak bersifat asam lagi. Pindahkan 
secara kuantitatif residu dari kertas saring ke dalam erlenmeyer kemudian ditambahkan $\mathrm{NaOH} 1.25 \mathrm{~N}$ sebanyak $200 \mathrm{ml}$. Didihkan dengan pendingin balik selama 30 menit. Sampel disaring menggunakan kertas saring yang telah dikeringkan dan diketahui beratnya. Residu dalam kertas saring dicuci menggunakan akuades hingga netral, $25 \mathrm{ml} \mathrm{K}_{2} \mathrm{SO}_{4} 10 \%$, dan 15 $\mathrm{ml}$ etanol $96 \%$. Residu beserta kertas saring dikeringkan dalam oven bersuhu $105^{\circ} \mathrm{C}$ selama 1-2 jam.

Kadar serat $(\%)=\frac{\text { bobot endapan } \text { kering }(g)}{\text { bobot } \text { sampel }(g)} \times 100 \%$

\section{Analisis Tekstur}

Sampel diletakkan di bawah aksesoris penekan atau menjepit sampel dengan aksesoris penarik kemudian dinyalakan. Selanjutnya menekan tombol untuk penekanan yang ada pada tensile strength. Setelah pengujian selesai, tekan tombol stop dan data telah tersimpan.

\section{Analisis Warna (Yuwono dan Susanto, 1998)}

Sampel ditempatkan dalam wadah plastik bening. Color reader dihidupkan. Tombol pembacaan diatur $L^{*}, a^{*}, b^{*}$, lalu ditekan tombol target. Hasil pembacaan dicatat.

\section{HASIL DAN PEMBAHASAN}

\section{Karakteristik Bahan Baku Apel Manalagi}

Data hasil analisis karakteristik bahan baku buah apel manalagi dapat dilihat pada Tabel 1.

Tabel 1. Hasil Analisis Bahan Baku Apel Manalagi

\begin{tabular}{lll}
\hline \multicolumn{1}{c}{ Parameter } & \multicolumn{1}{c}{ Jumlah } \\
\hline Kadar Air (\%) & 84.48 \\
Kadar Serat (\%) & 3.38 \\
Pektin (\%) & 1.28 \\
Asam (\%) & 0.05 \\
Total Gula (\%) & 6.25 \\
Vitamin C (\%) & 12.08 \\
Warna : & \\
Kecerahan (L) & 60.8 \\
Kemerahan (a*) & 7.6 \\
Kekuningan (b*) & 25 \\
Tekstur & 62.5 \\
\hline
\end{tabular}

\section{Karakteristik Kimia Lempok Apel Kadar Air}

Perlakuan tiga tingkat lama pemasakan dengan suhu $80 \pm 2^{\circ} \mathrm{C}$ dan proporsi penambahan maizena masing-masing memberikan pengaruh berbeda sangat nyata $(\alpha=0.01)$ terhadap rerata kadar air lempok apel, dan terdapat interaksi antara kedua faktor tersebut. Hal ini disebabkan Maizena merupakan pati yang dapat mengikat air di sekitarnya. Menurut Kusumawati (2013), pati memiliki kemampuan menyerap air karena memiliki kandungan gugus hidroksil dimana gugus hidroksil ini membentuk ikatan hidrogen dengan molekul air. Molekul pati mengandung gugus hidroksil yang sangat besar sehingga kemampuan menyerap airnya juga sangat besar. Semakin banyak kadarnya maka air yang terperangkap dalam matriks gel juga semakin banyak hal ini menyebabkan saat pengujian kadar air menggunakan metode oven, air yang diuapkan tidak maksimal sehingga kadar air lempok semakin tinggi konsentrasinya semakin sedikit karena air menjadi berikatan kimia dan menjadi susah untuk menguap saat diuji menggunakan metode oven. Semakin lama waktu pemasakan maka akan semakin sedikit kadar air lempok. Hal ini dikarenakan air di dalam 
bahan akan menguap seiring dengan lamanya waktu pemasakan. Penambahan maizena mempercepat proses pemasakan karena maizena akan mengikat air sehingga viskositas produk juga akan meningkat lebih cepat.

Tabel 2. Uji Beda Kadar Air Lempok Apel

\begin{tabular}{ccccc}
\hline Lama Pemasakan & $\begin{array}{c}\text { Konsentrasi } \\
\text { Maizena (\%) }\end{array}$ & $\begin{array}{c}\text { Rata-Rata } \\
\text { Kadar Air (\%) }\end{array}$ & Notasi & DMRT 1\% \\
\hline \multirow{3}{*}{1 jam } & 5 & $37.48 \pm 0.56$ & $\mathrm{~g}$ & 2.1833 \\
& 7.5 & $34.05 \pm 0.21$ & ef & 2.1833 \\
\multirow{3}{*}{$1.5 \mathrm{jam}$} & 10 & $32.67 \pm 1.31$ & de & 2.1675 \\
& 5 & $34.69 \pm 0.18$ & ef & 2.1489 \\
& 7.5 & $31.52 \pm 0.24$ & cd & 2.1256 \\
2 jam & 10 & $30.41 \pm 0.64$ & $\mathrm{c}$ & 2.0959 \\
& 5 & $26.93 \pm 3.14$ & $\mathrm{~b}$ & 2.0573 \\
& 7.5 & $26.52 \pm 0.91$ & $\mathrm{~b}$ & 2.0029 \\
\hline
\end{tabular}

keterangan: 1) Setiap data merupakan rerata dari 3 kali ulangan

2) Angka setelah \pm adalah nilai standar deviasi

\section{Kadar Vitamin C}

Perlakuan tiga tingkat lama pemasakan dengan suhu $80 \pm 2^{\circ} \mathrm{C}$ memberikan pengaruh yang sangat nyata terhadap kadar vitamin $\mathrm{C}$. Hal ini disebabkan karena semakin lama waktu pemasakan maka akan semakin sedikit kadar vitamin $\mathrm{C}$ dari lempok apel. Hal ini disebabkan karena karena vitamin $\mathrm{C}$ bersifat tidak stabil, larut dalam air dan mudah teroksidasi jika terkena udara (oksigen) dan proses ini dapat dipercepat oleh panas. Vitamin $\mathrm{C}$ mudah teroksidasi karena senyawanya mengandung gugus fungsi hidroksi $(\mathrm{OH})$ yang sangat reaktif. Dengan adanya oksidator gugus hidroksi akan teroksidasi menjadi gugus karbonil. Uckiah et al. (2009) menyatakan bahwa adanya proses pemanasan pada saat pemasakan akan mengakibatkan efek oksidasi vitamin $\mathrm{C}$ semakin tinggi, hal ini dikarenakan terjadinya kontak langsung antara bahan dengan udara/oksigen dan panas yang akan menyebabkan kerusakan pada asam askorbat semakin tinggi. Mahmud et al. (2009) menambahkan Pemanasan mempengaruhi kestabilan vitamin $\mathrm{C}$ sehingga kadar vitamn $\mathrm{C}$ menurun. Asam askorbat bersifat sangat sensitive terhadap pengaruh-pengaruh luar yang menyebabkan kerusakan seperti suhu, oksigen, enzim, kadar air dan katalisator logam. Asam askorbat sangat mudah teroksidasi menjadi L-dehidroaskorbat yang masih mempunyai keaktifan sebagai vitamin $\mathrm{C}$. Asam L-dehidroaskorbat secara kimia sangat labil dan dapat mengalami perubahan lebih lanjut menjadi asam L-diketogulonat yang tidak memiliki keaktifan vitamin C lagi (Andarwulan dan Koswara, 1989).

Tabel 3. Karakteristik Kimia Lempok Apel Manalagi Berdasarkan Perlakuan Lama Pemasakan

\begin{tabular}{ccc}
\hline Lama Pemasakan (Jam) & Kadar Vitamin C (mg/100g) & Kadar Total Gula (\%) \\
\hline 1 & $10.76^{\mathrm{c}} \pm 0.63$ & $23.41^{\mathrm{a}} \pm 1.64$ \\
1.5 & $9.57^{\mathrm{b}} \pm 0.87$ & $27.23^{\mathrm{b}} \pm 2.76$ \\
2 & $6.95^{\mathrm{a}} \pm 0.88$ & $31.77^{\mathrm{c}} \pm 1.61$ \\
\hline
\end{tabular}

Keterangan: Setiap data merupakan rerata dari 3 ulangan.

\section{Kadar Total Gula}

Perlakuan tiga tingkat lama pemasakan dengan suhu $80 \pm 2^{\circ} \mathrm{C}$ dan proporsi penambahan maizena masing-masing memberikan pengaruh berbeda sangat nyata $(\alpha=0.01)$ terhadap rerata kadar air lempok apel, namun tidak terdapat interaksi antara kedua faktor tersebut. Semakin lama waktu pemasakan maka semakin tinggi total gulanya. Hal ini disebabkan karena semakin lama pemasakan maka kadar air dari lempok akan semakin menurun yang menyebabkan kandungan total padatan terlarut dalam lempok menjadi 
meningkat, termasuk total gulanya. Adanya proses pemasakan mampu meningkatkan persentase total gula karena terjadi penurunan kadar air. Selama pemanasan dan adanya asam, sukrosa akan terhidrolisis menjadi gula reduksi dan dikenal dengan gula invert (Desrosier, 1988).

Tabel 4. Karakteristik Kimia Lempok Apel Manalagi berdasarkan Perlakuan Konsentrasi Penambahan Maizena

\begin{tabular}{cc}
\hline Konsentrasi Penambahan Maizena (\%) & Kadar Total Gula (\%) \\
\hline 5 & $26.20^{\mathrm{a}} \pm 4.53$ \\
7.5 & $27.46^{\mathrm{a}} \pm 3.48$ \\
10 & $28.75^{\mathrm{b}} \pm 4.00$ \\
\hline
\end{tabular}

Keterangan: Setiap data merupakan rerata dari 3 ulangan.

\section{Serat Kasar}

Perlakuan perbedaan tingkat kematangan buah apel dan konsentrasi penambahan maizena yang diberikan berpengaruh tidak berpengaruh nyata terhadap nilai kadar total gula lempok apel. Penambahan maizena tidak berpengaruh nyata terhadap kadar serat kasar disebabkan karena berdasarkan SNI 01-3727-1995 tentang tepung maizena memiliki serat sebesar maksimal $1.5 \%$. Serat kasar terdiri dari lignin dan selulosa, dimana kedua komponen tersebut merupakan serat tidak larut air (Tensiska, 2008). Sedangkan pada maizena, tidak terdapat lignin dan selulosa. Maizena mengandung pati sebesar $54.1-71.7 \%$, yang terdiri dari amilosa sebesar $27 \%$ dan amilopektin sebesar $73 \%$ (Daniati, 2005). Hal tersebut juga dijelaskan oleh Ismanto (2011) bahwa pati merupakan suatu polisakarida yang terdiri dari amilosa dan amilopektin.

\section{Karakteristik Fisik Lempok Apel Warna}

Perlakuan tiga tingkat lama pemasakan dengan suhu $80 \pm 2^{\circ} \mathrm{C}$ memberikan pengaruh sangat nyata $(\alpha=0.01)$ sedangkan proporsi penambahan maizena tidak memberikan pengaruh terhadap tingkat kecerahan lempok apel, dan tidak terdapat interaksi antara kedua faktor tersebut. Faktor yang menyebabkan bahan pangan mengalami perubahan warna adalah akibat pengaruh panas terhadap gula yang menyebabkan terjadinya reaksi pencoklatan non enzimatik. Pemasakan yang lama memungkinkan perubahan warna yang intens pada akibat reaksi mailard (Winarno, 2002). Perlakuan tiga tingkat lama pemasakan dengan suhu $80 \pm 2^{\circ} \mathrm{C}$ maupun proporsi penambahan maizena tidak memberikan pengaruh terhadap tingkat kemerahan lempok apel, dan tidak terdapat interaksi antara kedua faktor tersebut. Perlakuan tiga tingkat lama pemasakan dengan suhu $80 \pm 2^{\circ} \mathrm{C}$ memberikan pengaruh sangat nyata $(\alpha=0.01)$ sedangkan proporsi penambahan maizena tidak memberikan pengaruh terhadap tingkat kekuningan lempok apel, dan tidak terdapat interaksi antara kedua faktor tersebut. Faktor yang menyebabkan bahan pangan mengalami perubahan warna adalah akibat pengaruh panas terhadap gula yang terdapat pada lempok yang menyebabkan terjadinya reaksi karamelisasi atau pencoklatan non enzimatik. Penurunan tingkat kekuningan diduga karena reaksi maillard, dimana warna kuning lempok cenderung berubah lebih ke warna coklat. Selama proses pemasakan dapat terbentuk senyawa melanoidin sebagai hasil dari reaksi maillard yang mengakibatkan terjadinya perubahan warna kuning sampai coklat (Dewi, 2013). 
Tabel 5. Karakteristik Fisik Lempok Apel Berdasarkan Perlakuan Tingkat Kematangan Buah Apel

\begin{tabular}{cccc}
\hline Lama Pemasakan (Jam) & Tekstur $(\mathbf{N})$ & Warna $\left(\mathbf{L}^{\star}\right)$ & Warna $\left(\mathbf{b}^{\star}\right)$ \\
\hline 1 & $10.59^{\mathrm{a}} \pm 0.50$ & $59.38^{\mathrm{c}} \pm 2.53$ & $15.48^{\mathrm{b}} \pm 1.32$ \\
1.5 & $10.78^{\mathrm{a}} \pm 0.31$ & $57.63^{\mathrm{b}} \pm 2.33$ & $14.39^{\mathrm{a}} \pm 2.53$ \\
2 & $11.01^{\mathrm{b}} \pm 0.42$ & $52.00^{\mathrm{a}} \pm 2.17$ & $12.72^{\mathrm{a}} \pm 2.17$
\end{tabular}

Keterangan: Setiap data merupakan rerata dari 3 ulangan.

\section{Tekstur}

Perlakuan tiga tingkat lama pemasakan dengan suhu $80 \pm 2^{\circ} \mathrm{C}$ memberikan pengaruh nyata $(\alpha=0.05)$, sedangkan proporsi penambahan maizena memberikan pengaruh sangat nyata $(\alpha=0.01)$ terhadap total gula lempok apel namun tidak terdapat interaksi antara kedua faktor tersebut. Tekstur yang menentukan kekerasan dan kelunakan suatu bahan dapat berubah akibat pemasakan antara lain terdegradasinya protopektin yang tidak larut menjadi pektin yang larut dalam air oleh pemanasan atau asam dan terhidrolisisnya makromolekul menjadi mikromolekul (polisakarida menjadi gula sederhana) (Miku, 2013). Pemasakan menyebabkan air menjadi menguap sehingga kadar air dari lempok berkurang dan membentuk tekstur yang lebih keras atau padat. Menurut Ginting et al. (2007), semakin lama pemasakan maka akan semakin banyak air yang diuapkan, sehingga akan semakin kental produk yang dihasilkan. Maizena hampir seluruhnya terdiri dari zat pati yang bersifat mengikat air dan memiliki kemampuan untuk membentuk gel. Maizena memiliki sifat meningkatkan viskositas, sebagai pengental, memberi sifat keras, bersifat plastis, menyerap uap air yang berlebihan dan berkontribusi pada tekstur produk (Sudaryati et al., 2006). Semakin banyak maizena maka semakin banyak dan semakin kokoh gel yang terbentuk pada lempok apel.

Tabel 6. Karakteristik Fisik Lempok Apel Berdasarkan Perlakuan Konsentrasi Penambahan Maizena

\begin{tabular}{cc}
\hline Konsentrasi Penambahan Maizena (\%) & Tekstur (N) \\
\hline 3 & $10.41^{\mathrm{a}} \pm 0.32$ \\
5 & $10.92^{\mathrm{b}} \pm 0.31$ \\
7 & $11.06^{\mathrm{c}} \pm 0.39$
\end{tabular}

Keterangan: Setiap data merupakan rerata dari 3 ulangan.

\section{Karakteristik Organoleptik Lempok Apel Manalagi Kesukaan Terhadap Warna}

Hasil analisis sidik ragam menunjukkan bahwa perlakuan proporsi penambahan maizena dan lama pemasakan dengan suhu $80 \pm 2^{\circ} \mathrm{C}$ memiliki pengaruh yang sangat nyata $(\alpha=0.01)$ terhadap tingkat kesukaan panelis terhadap warna lempok apel. Hal ini berarti warna lempok apel pada setiap perlakuan menunjukkan adanya perbedaan yang cukup signifikan dan mampu dibedakan oleh panelis tidak terlatih. Hasil uji kesukaan warna lempok apel dapat dilihat pada Tabel 7.

Skor kesukaan panelis tertinggi yaitu pada konsentrasi maizena $7.5 \%$ dan lama pemasakan 1.5 jam yaitu sebesar 3.87 (suka). Sedangkan skor kesukaan panelis terendah diperoleh pada konsentrasi maizena 5\% dengan lama pemasakan 1 jam, yaitu sebesar 1.87 (tidak suka). Winarno (2008) menyatakan bahwa suatu bahan yang dinilai bergizi, enak dan teskturnya baik tidak akan dimakan jika memiliki warna yang tidak sedap dipandang atau memberikan kesan menyimpang dari warna seharusnya. Panelis cenderung menyukai warna yang tidak terlalu terang untuk produk lempok apel. Produk lempok apel dengan lama pemasakan 1.5 jam dan penambahan maizena sebesar $7.5 \%$ memiliki warna yang tidak terlalu terang maupun tidak terlalu gelap sehingga banyak panelis yang memilih. 
Tabel 7. Rerata Nilai Kesukaan Panelis terhadap Warna Lempok Apel Manalagi akibat Pengaruh Proporsi Penambahan Maizena dan Lama Pemasakan dengan Suhu $80 \pm 2^{\circ} \mathrm{C}$

\begin{tabular}{cccl}
\hline Lama Pemasakan & Konsentrasi Maizena (\%) & Skala & Keterangan \\
\hline \multirow{2}{*}{1 jam } & 5 & 1.90 & Tidak Suka \\
& 7.5 & 1.97 & Tidak Suka \\
& 10 & 1.87 & Tidak suka \\
$1.5 \mathrm{jam}$ & 5 & 2.20 & Tidak Suka \\
& 7.5 & 3.87 & Suka \\
\multirow{2}{*}{2 jam } & 10 & 2.90 & Agak Suka \\
& 5 & 3.73 & Suka \\
& 7.5 & 3.77 & Suka \\
& 10 & 3.75 & Suka \\
\hline
\end{tabular}

\section{Kesukaan Terhadap Aroma}

Hasil analisis sidik ragam menunjukkan bahwa perlakuan proporsi penambahan maizena dan lama pemasakan dengan suhu $80 \pm 2^{\circ} \mathrm{C}$ memiliki pengaruh yang sangat nyata $(\alpha=0.01)$ terhadap tingkat kesukaan panelis terhadap aroma lempok apel. Hal ini berarti aroma lempok apel pada setiap perlakuan menunjukkan adanya perbedaan yang cukup signifikan dan mampu dibedakan oleh panelis tidak terlatih. Hasil uji kesukaan aroma lempok apel dapat dilihat pada Tabel 8 sebagai berikut.

Tabel 8. Rerata Nilai Kesukaan Panelis terhadap Aroma Lempok Apel Manalagi akibat Pengaruh Proporsi Penambahan Maizena dan Lama Pemasakan dengan Suhu $80 \pm 2^{\circ} \mathrm{C}$

\begin{tabular}{cccc}
\hline Lama Pemasakan & Konsentrasi Maizena (\%) & Skala & Keterangan \\
\hline \multirow{2}{*}{ 1 Jam } & 5 & 2.57 & Agak suka \\
& 7.5 & 2.43 & Tidak suka \\
1.5 Jam & 10 & 2.58 & Agak suka \\
& 5 & 2.65 & Agak suka \\
& 7.5 & 3.40 & Agak suka \\
2 Jam & 10 & 2.70 & Agak suka \\
& 5 & 3.37 & Agak suka \\
& 7.5 & 3.25 & Agak suka \\
& 10 & 3.22 & Agak suka \\
\hline
\end{tabular}

Skor kesukaan panelis terhadap aroma lempok apel, dimana skor kesukaan panelis tertinggi yaitu pada lama pemasakan 1.5 jam dan konsentrasi maizena $7,5 \%$ sebesar 3.40 (Suka). Sedangkan skor kesukaan panelis terendah diperoleh pada lama pemasakan 1 jam dan konsentrasi maizena $7.5 \%$ sebesar 2.43 (tidak suka). Panelis lebih menyukai lempok yang memiliki aroma yang khas dan kuat. Buah buahan memiliki aroma yang khas dan berbeda, hal ini dikarenakan kandungan ester metil butanoat yang terdapat dalam buah apel. Aroma apel akan optimum ketika apel berada pada matang dikarenakan pada kondisi aerob gula akan diubah menjadi $\mathrm{CO}_{2}$ dan alkohol yang apabila bercampur dengan asam akan menghasilkan ester yang membuat aroma buah menjadi kuat (Khurniyati, 2015).

\section{Kesukaan Terhadap Rasa}

Hasil analisis sidik ragam menunjukkan bahwa perlakuan proporsi penambahan maizena dan lama pemasakan dengan suhu $80 \pm 2^{\circ} \mathrm{C}$ memiliki pengaruh yang sangat nyata $(\alpha=0.01)$ terhadap tingkat kesukaan panelis terhadap rasa lempok apel. Hal ini berarti rasa lempok apel pada setiap perlakuan menunjukkan adanya perbedaan yang cukup signifikan 
dan mampu dibedakan oleh panelis tidak terlatih. Hasil uji kesukaan rasa lempok apel dapat dilihat pada Tabel 9 sebagai berikut.

Tabel 9. Rerata Nilai Kesukaan Panelis terhadap Rasa Lempok Apel Manalagi akibat Pengaruh Proporsi Penambahan Maizena dan Lama Pemasakan dengan Suhu $80 \pm 2^{\circ} \mathrm{C}$

\begin{tabular}{cccc} 
Lama Pemasakan & Konsentrasi Maizena (\%) & Skala & Keterangan \\
\hline \multirow{2}{*}{ 1 Jam } & 5 & 2.43 & Tidak suka \\
& 7.5 & 2.53 & Agak suka \\
& 10 & 2.78 & Agak suka \\
$1.5 \mathrm{Jam}$ & 5 & 3.05 & Agak suka \\
& 7.5 & 3.68 & Suka \\
2 Jam & 10 & 2.83 & Agak suka \\
& 5 & 3.57 & Suka \\
& 7.5 & 3.45 & Agak suka \\
& 10 & 3.55 & Suka \\
\hline
\end{tabular}

Skor kesukaan rasa panelis pada lempok apel yang tertinggi yaitu pada lama pemasakan 1.5 jam dan konsentrasi maizena $7.5 \%$ yaitu sebesar 3.68 (suka). Sedangkan skor kesukaan panelis terendah diperoleh pada lama pemasakan 1 jam konsentrasi maizena $5 \%$, yaitu sebesar 2.43 (tidak suka). Khurniyati (2015) menyatakan bahwa rasa, aroma dan tekstur apel dihasilkan dari sekitar 230 komponen kimia dan beragam jenis asam seperti asam format, asam asetat dan 20 jenis asam lainnya. Serta kandungan alkohol yang berkisar 3040 jenis ester seperti etil asetat, dan 100 jenis karbonil seperti formaldehyde dan asetaldehid. Rasa manis pada buah apel matang disebabkan karena selama proses pematangan, kandungan pati dalam buah akan berubah menjadi gula-gula pereduksi yang akan menimbulkan rasa manis.

\section{Kesukaan Terhadap Tekstur}

Hasil analisis sidik ragam menunjukkan bahwa perlakuan proporsi penambahan maizena dan lama pemasakan dengan suhu $80 \pm 2^{\circ} \mathrm{C}$ memiliki pengaruh yang sangat nyata $(\alpha=0.01)$ terhadap tingkat kesukaan panelis terhadap rasa lempok apel. Hal ini berarti rasa lempok apel pada setiap perlakuan menunjukkan adanya perbedaan yang cukup signifikan dan mampu dibedakan oleh panelis tidak terlatih. Hasil uji kesukaan rasa lempok apel dapat dilihat pada Tabel 10 sebagai berikut.

Tabel 10. Rerata Nilai Kesukaan Panelis terhadap Tektur Lempok Apel Manalagi akibat Pengaruh Proporsi Penambahan Maizena dan Lama Pemasakan dengan Suhu $80 \pm 2^{\circ} \mathrm{C}$

\begin{tabular}{cccc} 
Lama Pemasakan & Konsentrasi Maizena (\%) & Skala & Keterangan \\
\hline \multirow{2}{*}{ 1 Jam } & 5 & 2.12 & Tidak suka \\
& 7.5 & 2.72 & Agak suka \\
1.5 Jam & 10 & 2.78 & Agak suka \\
& 5 & 2.58 & Agak suka \\
2 Jam & 7.5 & 3.05 & Agak suka \\
& 10 & 3.30 & Agak suka \\
& 5 & 3.15 & Agak suka \\
& 7.5 & 2.97 & Agak suka \\
& 10 & 3.45 & Agak suka \\
\hline
\end{tabular}

Skor kesukaan panelis tertinggi yaitu pada lama pemasakan 2 jam dan konsentrasi maizena 10\% yaitu sebesar 3.45 (agak suka). Sedangkan skor kesukaan panelis terendah 
diperoleh pada lama pemasakan 1 jam konsentrasi maizena 5\%, yaitu sebesar 2.12 (tidak suka). ekstur yang menentukan kekerasan dan kelunakan suatu bahan dapat berubah akibat pemasakan antara lain terdegradasinya protopektin yang tidak larut menjadi pektin yang larut dalam air oleh pemanasan atau asam dan terhidrolisisnya polisakarida menjadi gula sederhana (Miku, 2013). Pemasakan menyebabkan air menjadi menguap sehingga kadar air dari lempok berkurang dan membentuk tekstur yang lebih keras atau padat.

\section{Perlakuan Terbaik}

Pemilihan perlakuan terbaik parameter kimia dan fisik lempok apel manalagi yaitu kadar air, vitamin C, total gula, serat kasar, tekstur dan warna. Pemilihan perlakuan terbaik parameter organoleptik yaitu parameter warna, aroma, rasa dan tekstur. Lempok apel manalagi perlakuan terbaik menurut parameter kimia, fisik dan organoleptik terdapat pada lempok apel dengan perlakuan lama pemasakan 2 jam dengan konsentrasi maizena $10 \%$ dengan nilai kadar air $19.37 \%$, total gula $32.56 \%$, vitamin C $6.54 \mathrm{mg} / 100 \mathrm{~g}$, serat kasar $3.90 \%$, kecerahan $\left(\mathrm{L}^{+}\right) 50.17$, kemerahan $\left(\mathrm{a}^{+}\right) 3.17$, kekuningan $\left(\mathrm{b}^{+}\right) 14.30$, dan tekstur $11.35 \mathrm{~N}$. Nilai warna organoleptik lempok apel manalagi 3.75 (menyukai), nilai aroma organoleptik lempok apel manalagi 3.22 (netral), nilai rasa organoleptik lempok apel manalagi 3.55 (menyukai), dan nilai tekstur organoleptik lempok apel manalagi 3.45 (netral).

\section{SIMPULAN}

Lama Pemasakan memiliki pengaruh sangat nyata $(\alpha=0.01)$ terhadap kadar air, vitamin $\mathrm{C}$, total gula, tingkat kecerahan, tingkat kekuningan dan organoleptik lempok apel, memiliki pengaruh nyata $(\alpha=0.05)$ terhadap tekstur lempok apel, namun tidak memiliki pengaruh terhadap kadar serat kasar dan tingkat kemerahan lempok apel. Perlakuan konsentrasi Maizena memberikan pengaruh sangat nyata $(\alpha=0.01)$ terhadap kadar air, total gula, tekstur dan organoleptik, namun tidak memiliki pengaruh terhadap kadar serat kasar, kadar vitamin $\mathrm{C}$ tingkat kecerahan, tingkat kekuningan dan tingkat kemerahan lempok apel. Terdapat interaksi antara lama pemasakan dengan suhu tetap dan konsentrasi maizena pada kadar air. Perlakuan terbaik menurut parameter fisik, kimia, dan organoleptik yaitu pada perlakuan lama pemasakan 2 jam dengan konsentrasi penambahan maizena $10 \%$.

\section{DAFTAR PUSTAKA}

Andarwulan, N., dan Koswara, S. 1989. Kimia Vitamin. Rajawali Press. Jakarta AOAC. 1990. Official Methods of Analysis of The AOAC. Washington. USA

AOAC. 1995. Official Methods of Analysis $16^{\text {th }}$ Edition. Washington. USA

BPS Kota Batu. 2010. Sistem Pertanian Ramah Lingkungan: Anggota Kelompok Tani Makmur Abadi. http:// distanhut-kotabatu.org/hasil-panen-apel-kotabatu/jurnal. Tanggal akses: 30/08/2016.

Daniati, T. 2005. Pembuatan Bakso Ikan Cucut dengan Bahan Tambahan Jenis Tepung yang Berbeda. Tugas Akhir. Universitas Negeri Semarang. Semarang.

Desrosier, Norman W. 1988. Teknologi Pengawetan Pangan. UI Press. Jakarta.

Dewi, A.D. 2013. Pembuatan Lempok Pisang (Kajian Jenis Pisang dan Konsentrasi Madu). Skripsi. Universitas Brawijaya. Malang.

Ginting, E., Widodo Y., dan Prasetiaswati, N. 2007. Peningkatan Daya Guna dan Nilai Tambah Ubi Jalar Berukuran Kecil melalui Pengolahan Menjadi Saos dan Selai. Jurnal Penelitian Pertanian Tanaman Pangan 2:1, 110-122.

Ismanto A., dan Baharudin R.H. 2011. Analisis Kadar Pati , Lignin, dan Selulosa Pada Bambu Ampel (Bambusa vulgaris Schrad.) yang Direndam dalam Lumpur. Prosiding Seminar Nasional Kimia dan Pendidikan Kimia III. Universitas Negeri Sebelas Maret. Surakarta.

Khurniyati, M.I., dan Estiasih T. 2015. Pengaruh Konsentrasi Natrium Benzoat dan Kondisi Pasteurisasi (Suhu dan Waktu) Terhadap Karakteristik Minuman Sari Apel Berbagai Varietas: Kajian Pustaka. Jurnal Pangan dan Agroindustri 3:2, 523-529. 
Kusumawati, D.A., dan Putri, W.D.R. 2013. Karakteristik Fisik dan Kimia Edible Film Pati Jagung yang Diinkorporasi dengan Perasan Temu Hitam. Jurnal Pangan dan Agroindustri 1:1, 90-100.

Mahmud. 2009. Tabel Komposisi Pangan Indonesia. PT. Elex Media Komputindo. Jakarta.

Miku, R. 2013. Hubungan Pemanasan Terhadap Kualitas Fisikokimia Dodol Nangka di Industri Rumah Tangga "Dodol Karya Murni" Kota Batu. Laporan Praktek Kerja Lapang. Universitas Tribhuwana Tungga Dewi. Malang.

Sudarmadji, S., Haryanto, dan Suhardi. 1997. Prosedur Analisis untuk Bahan Makanan dan Pertanian. Liberty. Yogyakarta

Sudaryati, H., Latifah dan Lukita, S. 2010. Kajian Pati Jagung dan Bunga Rosela pada Kualitas Permen Lunak. Rekapangan 4:1, 11-16.

Tensiska. 2008. Serat Makanan. Jurnal Publikasi. Fakultas Teknologi Industri Pertanian. Universitas Padjajaran. Bandung

Uckiah, A., Goburdhun, D., and Ruggoo, A. Vitamin C Content During Processing and Storage of Pineapple. Nutrition and Food Science 39:4, 398-412.

Winarno, F.G. 2002. Kimia Pangan dan Gizi. Gramedia Pustaka Utama. Jakarta

Winarno, F.G. 2008. Kimia Pangan dan Gizi Edisi Terbaru. Embrio Biotekindo. Bogor

Yuwono, S.S dan Susanto. 1998. Pengujian Fisik Pangan. Universitas Brawijaya. Malang. 